\title{
Nigerian Pre-Service Teachers’ Science Anxiety
}

\author{
Oludipe Daniel Idowu \\ Integrated Science Department, School of Science, Tai Solarin College of Education, Omu-Ijebu, Nigeria \\ Email: daniel.oludipe@gmail.com
}

Received August 30 ${ }^{\text {th }}$, 2012; revised September 30 ${ }^{\text {th }}$, 2012; accepted October $16^{\text {th }}, 2012$

\begin{abstract}
Copyright (c) 2013 Oludipe Daniel Idowu. This is an open access article distributed under the Creative Commons Attribution License, which permits unrestricted use, distribution, and reproduction in any medium, provided the original work is properly cited.
\end{abstract}

\begin{abstract}
This study investigated science anxiety of two groups of would-be science teachers. A 20-item Science Anxiety Rating Scale (SARS) adopted from Bursal (2008) was used to gather data from the selected students. 360 science education students drawn from a college of education and faculty of education of a university in South-western part of Nigeria participated in the study. The sample comprised 200 (55.56\%) of the final year Bachelor's degree in education and 160 (45.44\%) of the final year Nigerian Certificate in Education students respectively. Finding of this study revealed that there was statistically significant difference in the science anxiety of the two categories of would-be science teachers.
\end{abstract}

Keywords: Anxiety; Bachelor Degree; NCE; Science; Pre-Service Teachers

\section{Introduction}

Science education plays an important role in the lives of individuals and in the advancement of science and technology for the development of mankind and the society in general (Alebiosu, 1998). Science education is the tool used to achieve scientific literacy which is the gateway to achieve scientific and technological advancement and economic survival (Alebiosu, 2003). The influence of science on a nation and her citizens could be seen from the production of basic human needs to social, political, educational, technological and economic advancement. The steps scientists take during scientific investigation (science process) and scientific products draw the attention of the society to the fact that science makes life comfortable.

Economically, advanced nations of the world are distinguished by the excellence of their educational system. Academic programmes of their educational institutions give special attention to science education programme. Towards revolutionizing Nigerian educational system, the 1969 conference gave birth to the National Policy on Education which brought changes to Nigerian educational system. For instance, in Nigeria, the National Policy on Education (2004: pp. 29-32) provided educational expenditure in science and technology.

Science anxiety is described as involving feelings of tension and anxiety that interfere with the manipulation of scientific equipment in a wide variety of ordinary life and academic situations. Science anxiety can also be described as a state of discomfort which occurs in response to situations involving scientific tasks which are perceived as threatening to self esteem. Such feelings are shown to lead to panic, tension, helplessness, fear, distress, shame, inability to cope, sweaty palms, nervous stomach, difficulty in breathing, and loss of ability to concentrate (Seligman, Walker, \& Rossenham, 2001).

Students' participation in science is affected by attitudes associated with science (Linn, 1992). International Assessment of Educational Progress (1992) reported that positive attitudes toward science influence students' performance and enrolment in science subjects. Further research examining psychological effects found that a student's self-concept of his ability to perform in science positively correlated with achievement (Oliver \& Simpson, 1988). Jegede (2007) carried out a research work on students' anxiety towards the learning of chemistry in secondary schools found that students, male and female, showed great anxiety towards the learning of chemistry and that the anxiety is higher in female than male.

Jegede also reported that wide coverage of the syllabus, low awareness of career opportunities, teachers and their teaching methods, and lack of teaching aids/laboratory were the causes of the Senior Secondary School students' anxiety towards chemistry. It has been observed that so many students fear science subjects (biology, chemistry, physics, \& integrated science) and such fear is characterized by mass disenchantment among the students towards the science subjects (Jegede, 2007). Students' anxiety towards the learning of any of the aforementioned science subjects leads to loss of interest in sciences at all levels of educational system (Keeves \& Morgenstern, 1992).

As said earlier, science education plays a vital role in the lives of individuals and in the advancement of science and technology for the development of mankind and the society in general. Science subjects are the prerequisites for the medical sciences, textile technology, agricultural science, synthetic Industry, printing technology, pharmacy, chemical engineering, science education, to mention just a few (Jegede, 2007). In spite of the Federal Government efforts to enhance students' interest in science right from the primary school level, students still see science subjects as bitter pills to swallow.

To solve this problem of science anxiety among primary pupils and secondary school students respectively, it is pertinent to focus on the pre-service science teachers because they are the implementors of the dictates of the science curriculum and the ones to create an anxiety-free classroom environment. In spite of the negative effects of students' anxiety on the science sub- 
jects, researchers had done little or nothing to examine the level of science anxiety, most especially among pre-service science teachers, in a Nigerian sample. It is against these backgrounds that the present research work critically examined the level of science anxiety among pre-service science teachers.

\section{Research Questions}

This study was conducted to answer the following questions:

1) Are the pre-service University science teachers science anxious?

2) Are the pre-service College of education science teachers science anxious?

3) Does any of the two categories exhibit significant science anxiety than the other?

4) Is there any significant difference in the level of anxiety exhibited by male and female Pre-service science teachers?

\section{Method}

360 pre-service science teachers (biology, basic science, chemistry, and physics) from the faculty of education of a University and a College of education in South-West Nigeria participated in the study. The Sample comprised 200 (55.5\%) of the $4^{\text {th }}$ year or final year university pre-service science teachers and $160(45.5 \%)$ of the $3^{\text {rd }}$ year or final year college of education pre-service science teachers. The 360 pre-service science teachers who participated in the study were randomly selected from the 800 (400 level) pre-service university science teachers in the aforementioned University, and 500 (300 level) pre-service college of education science teachers in the aforementioned college of education.

The only instrument used to gather data for this study was a structured questionnaire, Science Anxiety Rating Scale (SARS). Each item in the instrument was rated on a five-point Likerttype scale anchored by 1 = none, 2 = some, 3 = moderate, $4=$ much, and 5 = very much. The 20 -item Science Anxiety Rating Scale (SARS) (Bursal, 2008) was administered to the participants during one of the lectures in second semester. The instrument was validated by three senior colleagues (one from science education, one from guidance and counseling, and the third from test and measurement respectively). To ascertain the reliability of the instrument, it was administered to a set of students of the same level and status from another University and College of education respectively. Cronbach Alphas were computed to determine the reliabilities of scores obtained in this context. The SARS yielded an internal consistency (coefficient alpha) reliability of .83. Descriptive statistics and independent samples t-test were used to analyse the data collected.

\section{Results}

Total anxiety score was calculated from the 20 items on the SARS scale in order to ascertain the prevalence of science anxiety within each of the two groups. The minimum possible score was 20 and the maximum 100. A score of 60 is the middle point; hence higher scores indicate more science anxiety, while lower scores indicate less (or no) science anxiety. It was revealed from the data analysis that 110 students representing $30.56 \%$ had 48 as scores less than the 60 mid-point. 05 students scored 63 (1.39\%), 85 students scored 65 (23.61\%), 70 students scored 67 (19.44\%), while 90 students scored 76 (25\%) all of which were higher than the mid-point (60). This result indicates that majority of the prospective science teachers in this sample (250, 69.44\%) had high science anxiety, suggesting the prevalence of science anxiety among the participants.

Along programme line, it was revealed that 110 degree prospective science teachers had scores (48) less than the midpoint (60), while 90 degree prospective science teachers had scores higher than the 60 mid-point ( 63 \& 65). At the college of education level, all the 160 samples had scores higher than the mid-point (67 \& 76). This implies that the prospective college of education science teachers are more science anxious than their University counterparts. Examining the prevalence of science anxiety along gender line, it was revealed that 110 male students scored 48 representing 30.56\%, 60 male students scored 67 (16.66\%), while 190 female students (52.78\%) scored between 63 - 67 above the midpoint (60). 110 male preservice university students scored 48 , while 60 male prospective college of education students scored 67 (above the 60 midpoint). 90 female prospective university students scored 63, while 190 female prospective college students scored between 63 - 76 (above the midpoint). From the foregoing, female students are more science anxious than their male colleagues. Male preservice college of education science teachers are more science anxious than their university colleagues. Similarly, the female preservice college of education science teachers are more science anxious than their female university colleagues.

Further statistical analysis, using independent samples t-test, indicated in Table 1 that there was statistically significant difference in science anxiety between the prospective university and college of education science teachers $(t=.000$, sig). Similarly, from Table 1, there was statistically significant difference in the science anxiety between male and female prospective university and college of education science teachers ( $\mathrm{t}=.000$, sig).

\section{Discussion and Recommendations}

Statistical analysis of the individual's perception of their level of science anxiety, measured through the SARS, indicated the prevalence of science anxiety among pre-service teachers in this sample. Interestingly, this study revealed that the pre-service college of education teachers were more science anxious (72.06) than their university colleagues (55.50). Suggesting that programme of study might be a causative agent of pre-service teachers' science anxiety. The analysis also revealed that gender might be a predictive factor of students' science anxiety given the statistical difference in the male and female standard deviations $(54.71,70.16)$. This study has established the prevalence of science anxiety among the pre-service science teachers in Nigeria. Hence it is hereby recommended that lec turers handling the science courses, most especially at the college of

Table 1.

Independent samples t-test according to institutions and gender.

\begin{tabular}{|c|c|c|c|c|c|}
\hline Institution & Number & Mean & Std & Df & Sig. (2-tailed) \\
\hline University & 200 & 55.50 & 8.327 & \multirow{2}{*}{358} & \multirow{2}{*}{$.000^{* *}$} \\
\hline College & 160 & 72.06 & 4.479 & & \\
\hline \multicolumn{6}{|l|}{ Gender } \\
\hline Male & 170 & 54.71 & 9.107 & \multirow{2}{*}{358} & \multirow{2}{*}{$.000^{* *}$} \\
\hline Female & 190 & 70.16 & 5.604 & & \\
\hline
\end{tabular}


education level, should drop the conventional lecture method of teaching the pre-service teachers for other methods of teaching which are activity oriented that would make teaching and learning science more meaningful to the pre-service teachers. Workshops on the appropriate methods of teaching science should be regularly organized for the in-service teachers to update their existing knowledge.

\section{REFERENCES}

Alebiosu, K. A. (1998). Effects of two cooperative learning models on senior secondary school students' learning outcomes in chemistry. Unpublished Ph.D. Thesis, Ibadan: University of Ibadan.

Alebiosu, K. A. (2003). Readings in science education. Ibadan: Majestic Printers and Publishers.

Jegede, S. A. (2007). Students' anxiety towards the learning of chemistry in some Nigerian secondary schools. Educational Research Review, 2, 193-197.
Keeves, J. P., \& Morgenstern, C. (1992). Attitudes towards science: Measures and effects. In J. P. Keeves (Ed.), The IEA study of science III: NCE: 1970-1984 (pp. 122-140). New York: Pergamon.

Linn, M. C. (1992). Science education reform: Building the research base. Journal of Research in Science Teaching, 29, 821-840. doi:10.1002/tea.3660290806

Murat B. (2008). Changes in Turkish pre-service elementary teachers' personal science teaching efficacy beliefs and science anxieties during a science method course. Journal of Turkish Science Education, 5, 99-112.

NERDC (2004). National policy on education. Lagos: NERDC.

Oliver, J. S., \& Simpson, R. D. (1988). Influences of attitude towards science, achievement, motivation, and science self concept on achievement in science: A longitudinal study. Science Education, 72, 143155. doi:10.1002/sce.3730720204

Seligman Walkman, M. E. P., Walker, E. F., \& Rossenhan, D. L. (2001). Abnormal psychology (4th ed.). New York: W.W. Norton \& Company, Inc.

\section{Appendix}

\section{Science Anxiety Rating Scale}

Researcher: D. I. Oludipe, PhD

N.B.: This is not a test, so your opinion will not be judged as right or wrong. Any information you give will be treated with confidentiality and will be used for research purposes.

Directions: Some of the following activities may cause anxiety toward science and science learning.

Please select one of the boxes to indicate the level of anxiety you may or may not experience in each situation.

\section{Background Information}

Full Name:

Institution:

Male [

$$
\text { ] }
$$

ate $(\mathrm{X})$

Female [

Please indicate $(X)$ on the number $(1-5)$ to indicate how you feel about each statement below.

$\begin{array}{ll}\text { N.B.: None } & =1 \\ \text { Some } & =2 \\ \text { Moderate } & =3 \\ \text { Much } & =4 \\ \text { Very Much } & =5\end{array}$

\begin{tabular}{ccccccc}
\hline 1 & $\begin{array}{c}\text { Discussing scientific theories with my friends } \\
\text { outside the school }\end{array}$ & $\mathbf{1}$ & $\mathbf{2}$ & $\mathbf{3}$ & $\mathbf{4}$ & $\mathbf{5}$ \\
2 & $\begin{array}{c}\text { Explaining my ideas to people about } \\
\text { a novel event in nature }\end{array}$ & $\mathbf{1}$ & $\mathbf{2}$ & $\mathbf{3}$ & $\mathbf{4}$ & $\mathbf{5}$ \\
3 & $\begin{array}{c}\text { Being asked to justify an everyday life } \\
\text { decision by using science }\end{array}$ & $\mathbf{1}$ & $\mathbf{2}$ & $\mathbf{3}$ & $\mathbf{4}$ & $\mathbf{5}$ \\
\hline
\end{tabular}

\begin{tabular}{|c|c|c|c|c|c|c|}
\hline 4 & $\begin{array}{l}\text { Helping elementary/secondary school stu- } \\
\text { dents with his or her science project }\end{array}$ & 1 & 2 & 3 & 4 & 5 \\
\hline 5 & Walking to a science class & 1 & 2 & 3 & 4 & 5 \\
\hline 6 & Working on a project for my science class & 1 & 2 & 3 & 4 & 5 \\
\hline 7 & $\begin{array}{l}\text { Waiting for the result of a science } \\
\text { examination }\end{array}$ & 1 & 2 & 3 & 4 & $\mathbf{5}$ \\
\hline 8 & Reading science textbooks & 1 & 2 & 3 & 4 & 5 \\
\hline 9 & $\begin{array}{l}\text { Reporting scientific data from tables and } \\
\text { charts in class }\end{array}$ & 1 & 2 & 3 & 4 & 5 \\
\hline 10 & Doing a science experiment in laboratory & 1 & 2 & 3 & 4 & 5 \\
\hline 11 & $\begin{array}{l}\text { Presenting my findings from experiments to } \\
\text { the teacher }\end{array}$ & 1 & 2 & 3 & 4 & 5 \\
\hline 12 & Taking a science examination & 1 & 2 & 3 & 4 & 5 \\
\hline 13 & $\begin{array}{l}\text { Being asked to justify my answer in a } \\
\text { science class }\end{array}$ & 1 & 2 & 3 & 4 & 5 \\
\hline 14 & $\begin{array}{l}\text { Asking questions about what I do not } \\
\text { understand in a science class }\end{array}$ & 1 & 2 & 3 & 4 & 5 \\
\hline 15 & $\begin{array}{l}\text { Thinking about an abstract scientific } \\
\text { concept in class }\end{array}$ & 1 & 2 & 3 & 4 & 5 \\
\hline 16 & $\begin{array}{c}\text { Being asked by my teacher to explain } \\
\text { a novel event }\end{array}$ & 1 & 2 & 3 & 4 & 5 \\
\hline 17 & Using unit in science classes & 1 & 2 & 3 & 4 & 5 \\
\hline 18 & $\begin{array}{l}\text { Using mathematical equations in } \\
\text { science examinations }\end{array}$ & 1 & 2 & 3 & 4 & 5 \\
\hline 19 & $\begin{array}{l}\text { Recalling the textbook definition of } \\
\text { scientific laws }\end{array}$ & 1 & 2 & 3 & 4 & 5 \\
\hline 20 & $\begin{array}{l}\text { Being asked to explain scientific laws in } \\
\text { my own words }\end{array}$ & 1 & 2 & 3 & 4 & 5 \\
\hline
\end{tabular}

